\title{
FATHOM
}

\section{Silence, Secrecy and Sacredness in Hardy's Fiction}

The Example of Far from the Madding Crowd and Tess of the d'Urbervilles

Silence, secret et sacré dans la fiction de Hardy : l'exemple de Far from the Madding Crowd et Tess of the d'Urbervilles

\section{Gildas Lemardelé}

\section{OpenEdition}

\section{Journals}

\section{Electronic version}

URL: http://journals.openedition.org/fathom/358

DOI: $10.4000 /$ fathom.358

ISSN: 2270-6798

\section{Publisher}

Association française sur les études sur Thomas Hardy

\section{Electronic reference}

Gildas Lemardelé, «Silence, Secrecy and Sacredness in Hardy's Fiction », FATHOM [Online], 2 | 2013,

Online since 20 July 2013, connection on 03 May 2019. URL : http://journals.openedition.org/

fathom/358; DOl : 10.4000/fathom.358

This text was automatically generated on 3 May 2019. 


\section{Silence, Secrecy and Sacredness in Hardy's Fiction}

The Example of Far from the Madding Crowd and Tess of the d'Urbervilles

Silence, secret et sacré dans la fiction de Hardy : l'exemple de Far from the Madding Crowd et Tess of the d'Urbervilles

Gildas Lemardelé

\section{EDITOR'S NOTE}

This article was first published in Cycnos 26.2, "Thomas Hardy: Far from the Madding Crowd / Loin de la foule déchaînée” special number (Paris: L'Harmattan, December 2010): 13-28, and subsequently in the e-journal Revel: http://revel.unice.fr/cycnos/index.html?id=6368. It is reproduced here by special authorization from Cycnos.

1 Hardy's declared agnosticism will at first sight make it difficult to link the idea of silence to that of sacredness, in the sense that agnosticism can be interpreted as the felt absence of divine signs or messages - divine silence, or perhaps, divine secrecy. Admittedly, moments of silence in Hardy's fiction are sometimes associated with abyssal void or labyrinthic meanders, as in Tess of the d'Urbervilles, after Tess's confession to Angel of her misadventure with Alec ("They wandered on in silence", Hardy 2005b, 252), where the two protagonists literally find themselves probing a designified universe. Francesco Marroni has also noted the "persistence of suffering and silence - silence of fellow mortals, silence of nature, silence of God" in Hardy (65). Conversely, at other times, silence will be highly significant, and as a coherent and constructive interval, on both narrative and metaphoric level, it will allow for deeper meanings to emerge and make themselves known to the characters. In other words, silence in Hardy, this is no surprise, is ambivalent and both signifies the death and birth of meaning, but in either case it sustains the framework and keeps the novels' parts together, in the same way as Hardy 
remarked about silence at Tintern Abbey, on July 1, 1873 in The Life: "At Tintern, silence is part of the pile. Destroy that, and you take a limb from an organism..." (Hardy 1984, 96). One of the reasons for silence being so intrinsic to Tintern Abbey, is perhaps, as almost inevitably with religious edifices, its relation with questions of secrecy and of sacredness. Silence, as potentially self-referential, non-referential or infinitely multi-referential, opens up space for secrecy as the unknowable, the deep, inexpressible or deliberately unexpressed reality of something, as well as for the sacred, understood as the aweinducing, preserved separateness of something, and its privileged relation with the divine. This paper attempts to examine how silence, secrecy and sacredness are intertwined and interdependent, and how in some passages of the novels, when the narrative reaches a moment of stasis, or suspense, what could be construed as a silence in the narration, as in a music score, is in fact a moment of profusion, endowed with and eventually culminating in sacredness. Obviously, the sacred in Hardy will have to be qualified with regard to the author's standpoint, since, as Mary Rimmer says: "Few agnostics present such vexed and contradictory attitudes towards the sacred as Hardy" (32), and since Hardy himself was not loath to invoke the sacred for purely humoristic purposes, as for example in The Mayor of Casterbridge, when after Sunday service the men go to the pub, an activity described as a "sacred occasion" (Hardy 2004, 213). After having delineated the dramatic modes according to which silence and secrecy are breached in several instances of Hardy's novels, this paper will concentrate on two famous key scenes - one from Far from the Madding Crowd (ch. 43), when Bathsheba opens Fanny's coffin and uncovers a devastating secret, and the other from Tess of the d'Urbervilles (ch. 14), when the heroine baptizes her dying baby - which illustrate the interconnection between silence, secrecy and sacredness.

2 There are several memorable scenes in Hardy in which the disclosure or discovery of a secret has tragic consequences. Among the best examples would be the opening of Fanny's coffin, Clym's discovery of Eustacia's responsibility in his mother's death in Book $\mathrm{V}, 3$ of The Return of the Native, or the public display of Lucetta's secret past affair with Henchard in The Mayor of Casterbridge. These revelations are clearly dramatized and correspond to breaking-points in the narrative, when the loudness of the shock of disclosure resonates in Hardy's prose and in the ambient silence, as if the broken secrecy of truth had opened a void to be filled, and became the only thing heard, eventually to die out again into silence. In The Mayor of Casterbridge, the revelation is staged visually through the skimmington ride and through a manifest auditory climax and anti-climax:

'She's me-she's me-even to the parasol-my green parasol!' cried Lucetta with a wild laugh as she stepped in. She stood motionless for one second-then fell heavily to the floor.

Almost at the instant of her fall the rude music of the skimmington ceased. The roars of sarcastic laughter went off in ripples, and the trampling died out like the rustle of a spent wind. (Hardy 2004, 260)

3 The silence that follows the roar neatly coincides with Lucetta's breakdown, and the narrative comes to a halt until it is shaken again into motion, perhaps thanks to Lucetta's death as the next structuring event. In The Return of the Native the profound disturbance caused by the discovery by Clym of Eustacia's secret involvement in Mrs Yeobright's deadly journey is even more patently dramatized, and is given more room for extension 
before and after the crux of the critical confrontation between husband and wife. The crushing weight of silence for Eustacia ("burdened herself with a secret", Hardy 2005a, 313) and its slowing effect in the flow of the story are dispelled in the interval of a few seconds, but the blast of the revelation invades the whole atmosphere. Clym's preparation of the crisis ("Now I am going to reveal a secret to you", 314) and his artificial peal of laughter only reinforce his theatrical role in this chapter, and his dramatic disclosure of the secret comes as a violent blast, without doubt similar to that described in the second paragraph of the same chapter, through a Hardyan proleptic natural metaphor:

All the life visible was in the shape of a solitary thrush cracking a small snail upon the door-stone for his breakfast, and his tapping seemed a loud noise in the general silence which prevailed. (313)

4 Not unlike the snail, Eustacia is literally shell-shocked by the blow, so much so perhaps that she entrenches herself in her own sphere ("Eustacia was doggedly silent", 316). In Book I, 11 already the dramatic and emotional charge of her encounter with Wildeve was manifested in the absence of words ("Eustacia again remained in a sort of stupefied silence", 99), and on an even more literal level, after her implication in the Christmas play which led her to a first interview with Clym, hidden behind her mask, the dramatic import of silence was expressed in a poetic paradox that suggested the saturation of the episode ("The air was charged with silence and frost", 143).

5 In Tess, the baptismal scene of chapter 14 is of a different nature, as here the notion of secrecy appears not through disclosure of some truth that ought to have remained silenced, but through the secrecy of the proceeding itself, forced by the child's illegitimacy, but the revelation to Tess here is more directly of a seemingly religious order. The whole scene is intently dramatic again, and is one of the most poignant of the novel. Therefore the narrative culmination is worth focusing upon as it will reveal how the heroine gains access to some form of the sacred. At the core of this scene is Tess's desperateness to save her child from what her Christianity, with its naive superstitious layers, anticipates as the torments of the baby at the hands of diabolical forces ("she thought the child consigned to the nethermost corner of hell", "she saw the arch-fiend tossing it with his three-pronged fork", Hardy 2005b, 106). Hardy voluntarily piles up details that increase the solemnity of the scene and enhance the religious import of the ceremony ("the clock struck the solemn hour of one", "in the silence of the sleeping house", "she lit a candle", 106). In spite of the doubts that shake her belief in the validity of her performance, Tess finally gets enticed by her own fervour, and the death of her newborn is no obstacle to the divine inspiration she seems to be drawing from the ritual. Although her liturgy is marked by a somewhat poor beginning ("murmured incoherent supplications for a long while", 106), Tess gradually seems to be seized with the special power of the atmosphere she herself builds up, and she clearly undergoes some sort of transformation ("her high enthusiasm having a transfiguring effect", 107), which according to Virginia Woolf confers upon her a form of royalty, underlined by the narrator ("a touch of dignity which was almost regal", 107; Woolf 253), but which however is more convincingly to be related to the divine, or the iconographic. Indeed Hardy turns the young mother into an object of worship and reverence, as is seen first through her siblings' attitude with terms such as "awe-stricken" (106) or "full of a suspended wonder" (107), and second through the escalating clarity of her metamorphosis into a saintly figure, very possibly akin to the Virgin Mary in traditional 
representations ("immaculate beauty", "glowing irradiation", 107). Tess's transformation under Hardy's pen is intent on sanctifying the heroine, especially when he writes about her entrancing inspiration ("The ecstasy of faith almost apotheosized her", 107), and uses the first etymological acceptation of the word to throw into relief her passage, as in ancient Rome, from an earthly status to a divine one. The mother's godly transfiguration also transpires in the possible analogy between baptismal water and sacred love ("poured forth from the bottom of her heart the thanksgiving that follows", 107), as well as in the inner peace, almost Christ-like countenance, resignation and acceptation, she is said to experience: "The calmness which had possessed Tess since the christening remained with her in the infant's loss" (108).

6 In Far from the Madding Crowd, Bathsheba is dying to know Fanny's secret ("Would to God you would speak and tell me your secret, Fanny", Hardy 1986, 227). Up to this point the link between silence and secrecy could not be more evident, as the atmosphere is saturated with muteness, both because of pervading death, and because of the untold secret. Yet by forcing the coffin open Bathsheba breaks Fanny's secret, and by the same token, her silence as well as Fanny's silence. After the first effusions of her shock, which again resonate in the ambient silence ("the silent room added length to her moan", 228), a new sort of peace seems to settle in, and when Hardy writes that the "room was silent as a tomb" (229), which as a matter of fact it is, the scene is now prepared for the intervention of the sacred. Like Tess, when Bathsheba kneels in fervent prayer by the open coffin, not in the hope of resurrection but in the hope of comprehension, she seems to be visited by unprecedented revelations of a spiritual kind. Again, at a crucial moment in the narrative, Hardy becomes an iconographer. Although Bathsheba's imagination initially perceives Fanny's corpse in the light of her hatred for her rival ("garish light of mockery", "ironical smile", 228), the focus changes and Fanny is soon described in terms that make her a religious icon: "Fanny's face was framed in by that yellow hair of hers", "the innocent white countenance expressed a dim triumphant consciousness" (228), "the light slanted down, distinctly enkindling the cold features of both mother and babe" (230) - here the choice of "babe" is not devoid of biblical echoes". More importantly, Bathsheba's sudden prayer channels her way through to momentary serenity and understanding of some truth that had escaped her up to that moment of the story, and what has often been analyzed by critics as her metamorphosis in chapter 44 , when she secludes herself in a thicket, under an oak until the following morning, is in fact already initiated in this episode of a religious dimension. Before prayer Bathsheba's tears already have a mysterious meaning ("of a nature indescribable, almost indefinable", 228), and after prayer she emerges as a new woman, who has found relief in reverence ("when Bathsheba arose it was with a quieted spirit", 229). That Hardy should use the word "atonement" (229) instead of "forgiveness" to describe her disposition after prayer is indicative of the spiritual experience she has gone through. Bathsheba has left her fright behind, having been reconciled with silence, in that she has gained knowledge of its rhetoric, or to remain consistent with the surface imagery of the scene, has been illuminated about its essence.

7 I say "surface imagery" because as always with Hardy things should not be taken at facevalue. Timothy Hands has written about Hardy's delight in the contrast or even antithesis 
between the secular and the sacred (49-50). Perhaps the idea can be taken a step further, and my point is to show that Hardy's use of the secular and of the sacred in the examples given above results more in a blending than in a contrast. Of course Hardy does not fail to remind his reader of the distance between himself and images of Christianity, as is felt through Tess's diabolical visions, familiar "in this Christian country" (Hardy 2005b, 106), he writes, with surreptitious irony as to the folkloric aspect of this kind of belief. Similarly, Tess's direct appeals to God's mercy ("O merciful God, have pity; have pity", 106) betray the author's denunciation of godly injustice and muteness, as surely he points it out when the children acquiesce to Tess's liturgy ("they again piped into silence 'Amen!", 107), where "into silence" may just as well be meant to signify "into nothingness".

8 Yet for all his irony, Hardy cannot do without the sacred. Thus Tess is endowed with the power to "christen", etymologically to "make Christian" (OED), and more significantly she also seems to have the power to make silence: "She sprinkled the water, and there was silence" (107). Although the lure of irony probably lurks somewhere behind, Hardy's prose here mimics the genetic prose ("And God said, Let there be light: and there was light", Genesis 1,3), which indirectly assimilates Tess to God engaged in cosmogenesis. Even if this silence following baptism could be construed as the apex of sacredness or conversely of emptiness, if we bear in mind that the village vicar will refuse to validate Tess's baptism of her child, a sort of desacralization of her act, the fusion of the sacred and the secular elaborated by Hardy is hardly deniable. Once baptism is performed, Hardy still ironizes as to the mother's "confidence in the efficacy of the sacrament", but at the same time he magnifies her into "a divine personage" (108), a secular saint ("a pure woman", according to the subtitle of the novel). Tess, Teresa by her true name, is made holy by her sacrifice later in the novel, but in chapter 14 she is also a sinful and selfaccusing saintly figure who brands her child with the mark of punishment by naming him Sorrow after God's retribution for Adam and Eve's fault ${ }^{2}$. Hardy had already resorted to a comparable amalgamation in Far from the Madding Crowd: after having opened the coffin, Bathsheba is described as in a state of trance ("quivering with emotion, a mist before her eyes, and an excruciating pulsation in her brain", Hardy 1986, 228). Devised to illustrate Bathsheba's overwhelming grief, this passage puzzlingly evokes images of revelations, and the relatively ponderous adjective "excruciating" (228) should not go unnoticed, as its Latin root (crux), invites comparisons with Eustacia's predicament on Egdon Heath, which she describes as "my cross" in Book I, 9. Hardy still goes further in his appropriation of the sacred when, in the same chapter, he almost profanely takes up biblical material to describe the death of Bathsheba's marriage:

At these words there arose from Bathsheba's lips a long, low cry of measureless despair and indignation, such a wail of anguish as had never before been heard

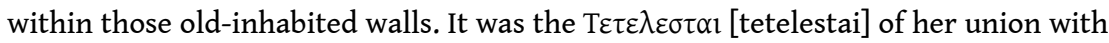
Troy. (231)

The last words of Christ on the cross ("It is finished"), rendered in pompous Greek, put the finishing touch to the secular-sacred blend, in a manner very much like what Hardy does again in Jude the Obscure, when his recitation of the Nicene creed and of Job wrenches the sacred from its context to fit his purpose (see Rimmer 29). Therefore the sacred is exploited and then subverted in a way that suggests both assimilation and rejection, a characteristic which is highly constitutive of the dramatization of the scene. Along with silence and secrecy, religious imagery partakes of a form of dramatic sacredness, a 
sacredness that is brought forth through a prose that paradoxically appears as iconoclastic and iconographic at the same time.

In those two key scenes the characters thus access a truth of a superior kind, which operates a deep transformation in them, presented through religious images or metaphors, but which in fact is anchored in secular reality, as Hardy reminds us more or less surreptitiously. The religious imagery reinforces pivotal moments of revelatory intensity and of personal transfiguration, only to subvert them. Nevertheless, Hardy shows himself consistent in his ambiguity with regard to religious matters, and in this respect it remains unclear whether his work of rewriting and adaptation secularizes the sacred, or whether it sacralises the secular, probably because, in an idiosyncratic manner, he does both. Through interstices of silence and secrecy, whether preserved or brutally violated, the sacred in Hardy emerges as a form of artistic, almost literary device - just as in Christian orthodoxy the sacred fulfils aesthetic functions. Hardy twists Christian elements and allusions to serve precise purposes, sometimes to ironically secular use, but in the same ironical manner his method shows heavy reliance, if not dependence, on the very imaginative power of those religiously endowed tropes he endeavoured to subvert.

\section{BIBLIOGRAPHY}

The Bible, Authorized King James Version With Apocrypha, Oxford: OUP (World's Classics), 1998.

Hands, Timothy, Thomas Hardy: Distracted Preacher? Hardy's Religious Biography and its Influence on his Novels, Basingstoke and London: Macmillan, 1989.

Hardy, Thomas, Far from the Madding Crowd (1874), New York \& London: Norton, 1986.

Hardy, Thomas, The Return of the Native (1878), Oxford: OUP (World's Classics), 2005.

Hardy, Thomas, The Mayor of Casterbridge (1886), Oxford: OUP (World's Classics), 2004.

Hardy, Thomas, Tess of the d'Urbervilles (1891), Oxford: OUP (World's Classics), 2005.

Hardy, Thomas, Jude the Obscure (1895), London: Penguin Classics, 1998.

Hardy, Thomas, The Life and Work of Thomas Hardy, ed. Michael Millgate, London: Macmillan, 1984.

Marroni, Francesco, “'At Day-Close in November': Hardy and the Spectral Signs of a Landscape”, The Hardy Society Journal 5.2 (Summer 2009): 56-65.

Rimmer, Mary, “"My Scripture Manner': Reading Hardy’s Biblical and Liturgical Allusion,” Thomas Hardy Reappraised: Essays in Honour of Michael Millgate, ed. Keith Wilson, Toronto: U Toronto P, 2006, 20-37.

Woolf, Virginia, "The Novels of Thomas Hardy", The Common Reader vol. II, London: Vintage, 2003, 245-257. 


\section{NOTES}

1. See Luke 2,12 (KJV): "And this shall be a sign unto you; Ye shall find the babe wrapped in swaddling clothes, lying in a manger." The image thus conjured up is that of traditional representations of the Nativity scene.

2. Genesis 3, 16: "Unto the woman he said, I will greatly multiply thy sorrow and thy conception; in sorrow thou shalt bring forth children."

\section{ABSTRACTS}

For Hardy the professed agnostic, silence may correspond to the absence of speech or of divine signs. In that case, the connection between silence and the sacred might not seem obvious at first sight.

Yet though silence, which is highly significant in each Hardy novel, constitutes on many occasions an abyssal or labyrinthic void, it also appears as a coherent and constructive interval. Silence and the secrets it harbours sometimes play an essential part in the organic structure of the novel, connecting the different parts of the narrative into a consistent whole. In such silent interstices one may sometimes find the presence of sacred or highly religious elements as well as the sense of a perfect epistemological order. This is often carried forth by the presence of death, a systematic concern of Hardy's. The episode around Fanny's coffin in Far from the Madding Crowd and the baptismal rite in Tess thus both illustrate that interconnection between silence, secrecy, and sacredness.

The article aims at examining the links between the three notions and at understanding how the sacredness depicted by Hardy is not of a strictly religious or theological sort, but is rather paradoxically rooted in the human and the secular.

Pour Hardy, agnostique déclaré, le silence peut renvoyer à l'absence de parole ou de signes divins. Dans ces conditions, l'articulation entre silence et sacré n'apparaît pas d'emblée comme évidente.

Pourtant, bien que le silence, prégnant dans chacun des romans, se fasse en maintes occasions espace abyssal ou béance labyrinthique, il s'offre aussi comme intervalle dans lequel la cohérence s'établit et se construit. Le silence, et les secrets qu'il abrite, tient parfois un rôle essentiel dans l'édifice romanesque, puisqu'il assure le lien entre les parties constitutives du récit. Dans ces interstices silencieux s'affirment parfois la présence d'un contenu sacré ou en apparence éminemment religieux, et la perfection d'un ordre épistémologique, notamment par le biais de la mort, qui occupe le romancier de manière systématique. On en voit des exemples dans l'épisode du cercueil de Fanny dans Far from the Madding Crowd, ou dans le rite baptismal de Tess, où coïncident silence, secret et sacré.

Cette étude propose donc d'explorer les liens qui unissent ces trois notions et de voir en quoi cette forme de sacré décrite par Hardy n'est pas strictement religieuse ou théologique, mais, paradoxalement, est plutôt ancrée dans l'humain et le séculier. 
INDEX

oeuvrecitee Far from the Madding Crowd, Tess of the d'Urbervilles, Mayor of Casterbridge (The), Return of the Native (The)

Keywords: silence, novel, sacred, secret, secular, religion, Bible, death

Mots-clés: silence, roman, sacré, secret, séculier, religion, Bible, mort

\section{AUTHOR}

\section{GILDAS LEMARDELÉ}

Université de Caen Basse-Normandie Doctorant

Professeur agrégé 